\title{
Thinking About Distancing from Israel
}

\author{
Steven M. Cohen · Ari Y. Kelman
}

Received: 17 May 2009/Accepted: 4 June 2010/Published online: 29 August 2010

(C) The Author(s) 2010. This article is published with open access at Springerlink.com

Are non-Orthodox American Jews growing more distant from Israel? That question indeed is the central issue in this exchange of views between our friends and colleagues-Ted Sasson, Charles Kadushin, and Len Saxe—and ourselves. Their scholarly contribution above presents their response to their reading of our Beyond Distancing (Cohen and Kelman 2007). In that report, one that we prepared for the larger lay public rather than an academic audience, we presented results from our 2007 national survey of American Jews.

\section{The Distancing Phenomenon: The Evidence, the Explanation}

Our survey analysis delineated several pieces of evidence pointing to diminished attachment to Israel among younger Jews. "In sharp contrast to their parents and grandparents, non-Orthodox younger Jews, on the whole, feel much less attached to Israel than their elders." Our survey contained numerous measures of Israel attachment leading us to claim that the age-variations are not the result of a peculiarity in one or another measure of Israel attachment. Rather, drawing upon many survey questions, we discerned a deep-seated, and broad-based gap in Israel attachment between old and young. The following graphs illustrate our findings:

S. M. Cohen $(\bowtie)$

Hebrew Union College-Jewish Institute of Religion, New York, NY, USA

e-mail: steve34nyc@aol.com

A. Y. Kelman

University of California, Davis, CA, USA

e-mail: aykelman@ucdavis.edu 


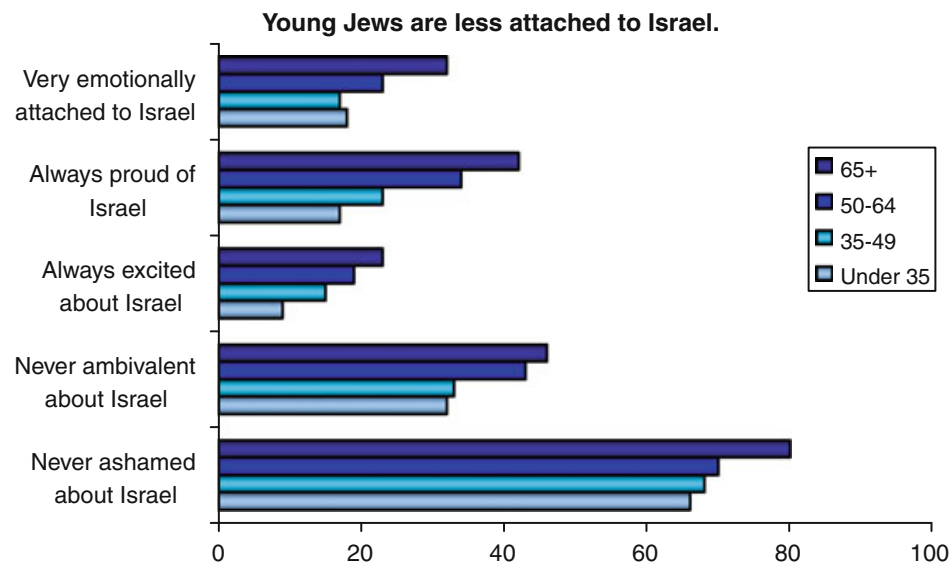

Young Jews express less caring for Israel.

Caring about Israel is important part of being a Jew

Worried US will not be an ally of Israel

Israel's destruction would be a personal tragedy

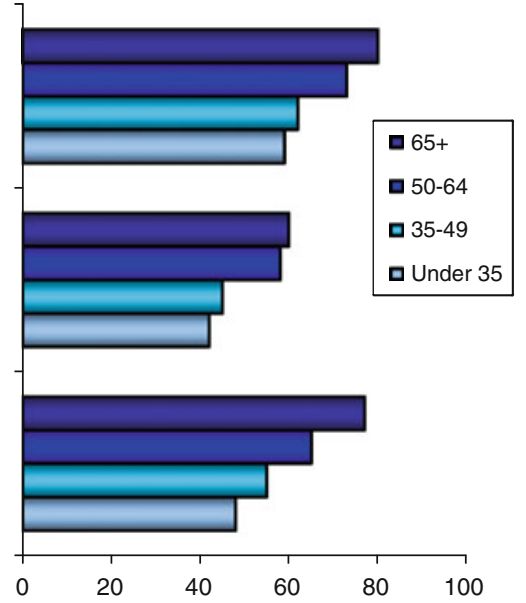

Young Jews are less engaged with Israel.

Talk about Israel to Jewish Friends Talk about Israel to Drawn to stories
about Israel

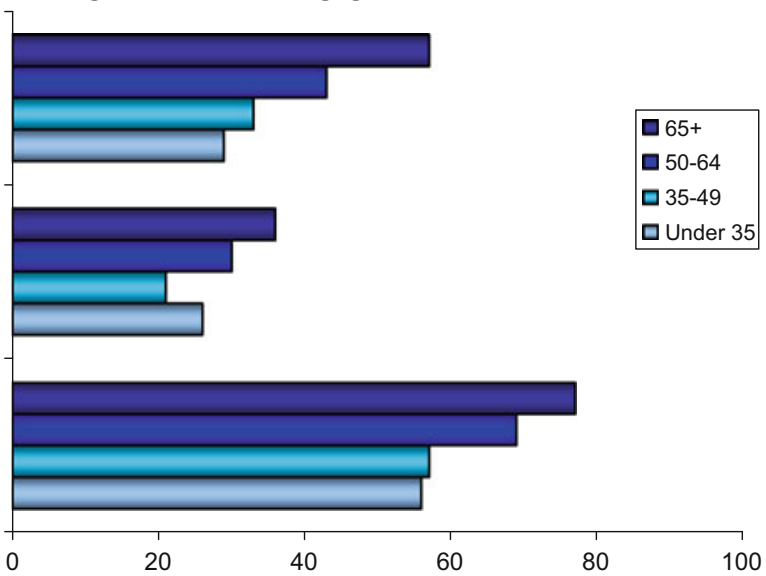



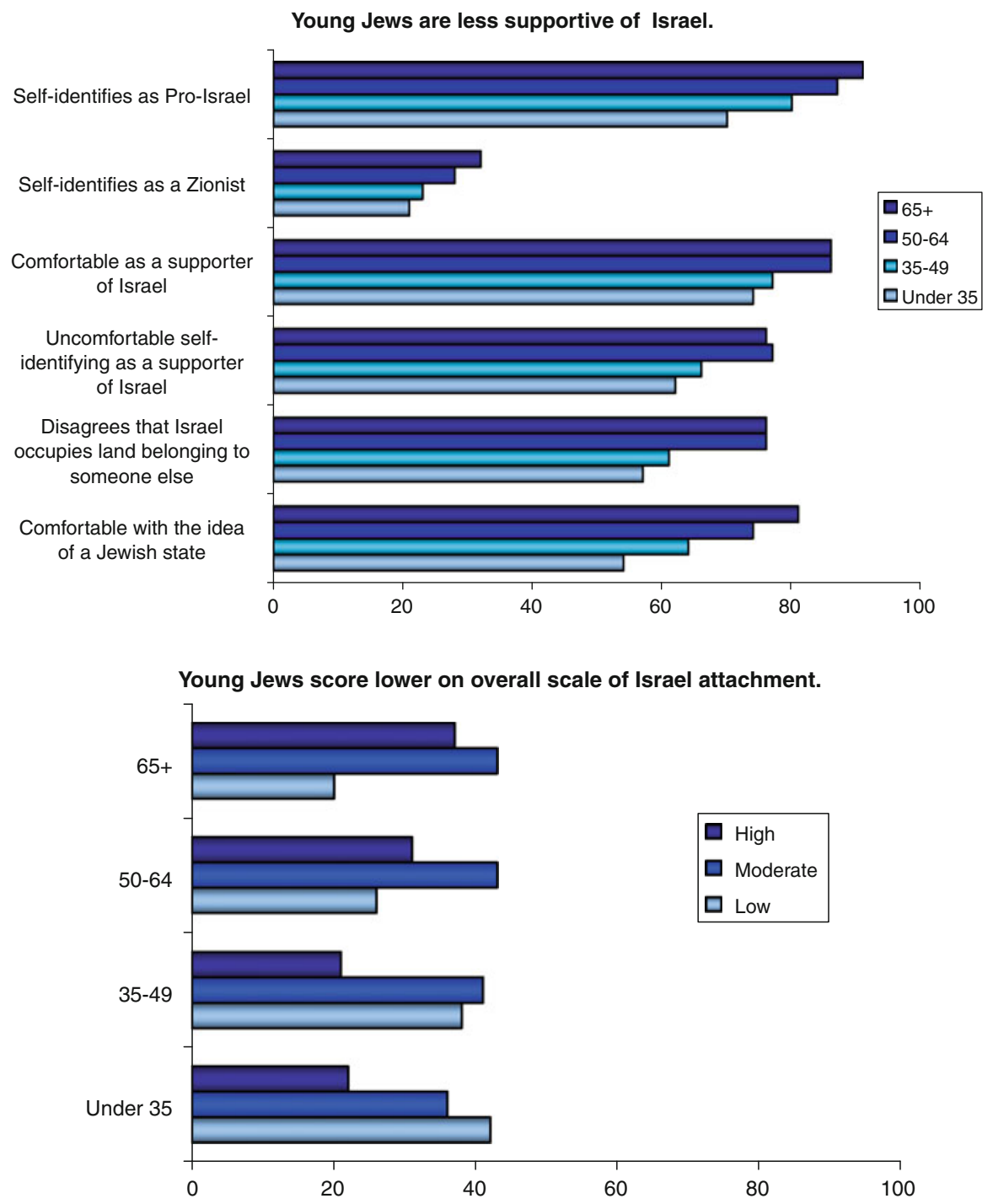

We also found that larger numbers of younger Jews scored high on none of our principal indicators of Israel attachment, leading us to write, "In the past one could speak of mounting indifference to Israel as the major orientation of the unengaged. In contrast, these days we find instances of genuine alienation as many more Jews, especially young people, profess a near-total absence of any positive feelings toward Israel."

We were also careful to provide a nuanced interpretation of our results, saying, "At the same time, the bottom has not fallen out entirely: about $60 \%$ of younger adult Jews who are not Orthodox profess some attachment to Israel. While less attached than their elders, most younger adult Jews still view Israel positively."

Why are young Jews more distant from Israel than their elders? In contrast to conventional wisdom, we found that political inclinations associated with possible 
discomfort with Israeli government policies are not the root cause of young people's distancing from Israel. Among the non-Orthodox, those with left-leaning and rightleaning political identities hardly differ with respect to Israel attachment. In fact, contrary to widely held beliefs among the policy public, in some respects younger right-of-center Jews are actually more distant from Israel than left-of-center Jews of their same age range. The reasoning for this counter-intuitive observation is intriguing and significant. It centers on how relatively right-wing Jews get to be that way. It seems that relatively right-leaning politics among Jews derive from intermarriage and weak Jewish social networks (few Jewish friends). Identified Jews differ from Americans in their politics (more liberal and Democratic) and in their passion for Israel. Less identified Jews move toward the American center: they are both more centrist in their politics and less attached to Israel.

Not surprising to anyone, we found that travel to Israel is associated with stronger attachment to Israel, in part as cause and in part as effect-pro-Israel Jews more frequently travel to Israel, and, at the same time, Israel travel makes Jews more attached to Israel. Accordingly, we opined that raising travel rates among young people may help counteract their declining attachment to Israel. But travel alone, or lack of it, does not explain the distancing of the younger generation, especially because younger Jews tend to travel to Israel more than their predecessors (thanks, in part to Birthright Israel and Masa, the effort to recruit young adult Jews to longerterm programs in Israel).

In searching for the major drivers of the age-related decline in Israel attachment, we settled upon intermarriage as a principal explanation. Several considerations led us to this inference. First, intermarriage rates continue to climb decade by decade and cohort by cohort (among the non-Orthodox). Second, intermarried Jews are far less attached to Israel than in-married Jews. Third, the Jewish children of the intermarried are far less attached to Israel than the children of the in-married. Hence, more intermarriage today (among the non-Orthodox) means less Israel attachment tomorrow, again, among the non-Orthodox. The contrast between intermarried Jews and others emerges quite clearly as the following graph demonstrates:

\section{Mixed married Jews score far lower than in-married or non-married Jews on scale of Israel attachment.}

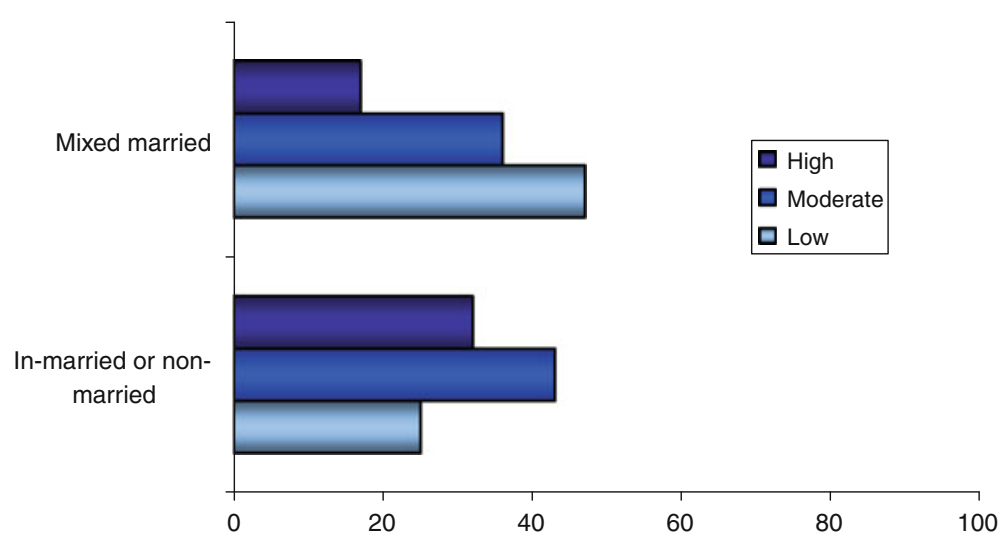


Moreover, not only are the intermarried more detached from Israel, our data clearly point to a growing gap in Israel attachment between the intermarried and others. We constructed a measure of "alienation" from Israel representing those with consistently low scores on several attachment questions. We found that while alienation bears an inconsistent relationship with age among the in-married and non-married, alienation grows considerably with youthfulness among the intermarried. In other words, as the following graph illustrates, the intermarried under 35 report the highest levels of alienation from Israel, that is, the lowest levels of attachment to Israel:

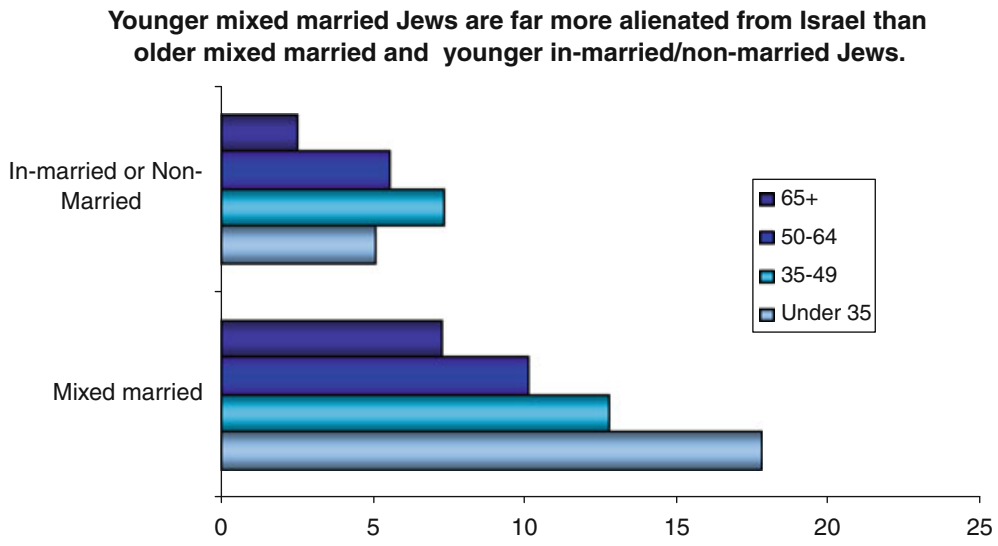

These patterns, taken in their entirety, led us to conclude:

The erosion in Israel engagement has taken place over the entire age spectrum, from elderly, to upper-middle-aged, to lower-middle-aged, to young adult. The phenomenon has the markings of a birth-cohort effect rather than a family life-cycle effect. A family life-cycle effect would show strong relationships with marriage or the advent of children. We might see increases and decreases in attachment over the life-cycle as family circumstances change. But here, the trend lines are fairly consistent with age: each drop in age is associated with a drop in Israel attachment. While the evidence is not and cannot be conclusive [owing to the limitations of our data], it does appear that levels of attachment are linked to when people were born and came to adulthood, rather than a particular stage in life. We see a pattern of shifting (declining) attachment to Israel stretching over 50 years, from those who are now 65 and older down to those in their 20s.

In their analysis of the American Jewish Committee's surveys of Jews-byreligion, Sasson, Kadushin, and Saxe present a variety of considerations, findings, and conclusions with which we share common ground. Their paper replicates and further validates several patterns that had been noted both in our 2007 paper, and/or in the several papers one of us has published over the years, starting in the 1980s. Among our several areas of concurrence are the following:

(1) Younger Jews are more distant from Israel than older Jews.

(2) Political variations provide no explanation for the age variations.

(3) Intermarried Jews score lower on Israel attachment than older Jews. 
(4) Travel is strongly associated with higher levels of attachment.

So where, then, do the two research teams differ? In our view, we differ most significantly over whether non-Orthodox Jews are experiencing a decline in attachment to Israel. We (Cohen and Kelman) believe that everything we know about American Jews, including the hard evidence and the reasoned analysis we offer above, all point to that straightforward observation.

In contrast, our colleagues at the Cohen Center arrive at a cautiously worded contrary conclusion: "There is no consistent evidence of distancing [from Israel] in the available survey data." And, not surprisingly, given their extensive knowledge accrued over years of evaluating Taglit-Birthright Israel, they add, "The popularity of Israel experience tours among teens and young adults-in particular, TaglitBirthright Israel—suggests a strong possibility that American Jewish ties to Israel may be stronger in the future."

We agree with them that they found "no consistent evidence of distancing in the survey data." But the standard of "consistent evidence" (in this case, presumably declining attachment to Israel over the decades for major segments of the American Jewish population) is not the only basis upon which we ought to arrive at our analyses of the data. Our argument is based on interpretation rather than mere extrapolation. And the several points of concurrence aside, we do encounter several points of disagreement.

\section{It's Not About the Orthodox}

One difference is critical: Our two papers are dealing with overlapping but differing populations. We (Cohen and Kelman) have been referring to non-Orthodox American Jews. Following upon our work on the non-Orthodox, they (Sasson, Kadushin and Saxe) chose to focus upon all American Jews who declare their religion to be Judaism (about which more below), including the Orthodox.

To be perfectly clear, we have no doubt that Orthodox Jews remain attached to Israel and that their attachment may well be growing, as demonstrated in the large number who study in Israel and the many who make aliyah. With the Orthodox included in the analysis (as in their paper, but not ours), we would entirely expect Israel attachment among Jews-by-religion to have held steady over the past decade. In fact, our colleagues' finding of (mere) stability of Israel attachment in their select sample of Jews whose religion is Judaism and which include the Orthodox may, ironically, point to even more weakness in Israel attachment than we earlier suspected. For if the Israelinclined segment of American Jews is only maintaining its attachment levels over the years, then what can we expect of those who are non-Orthodox and claim to be Jewish despite eschewing any identity with Judaism — a growing portion of American Jewry?

\section{It's Not All About the Jews-by-Religion}

The differences over which Jews we are talking about become even more pronounced when we take into account that the AJC data pertain to a segment of 
American Jews that is declining in number and increasingly selective in character: those who say that their religion is Jewish. These surveys exclude Jews (about 20\% and growing) who identify as Jewish, but see their religion as "none." To be sure, we have no other way of obtaining a national sample of American Jews, except at great cost and we are compelled to rely on those who identify their religion as Jewish. Such samples provide valuable evidence, but must be interpreted with an eye to the mounting number of Jews-not-by-religion who perforce fall outside these samples. This argument turns on how we are to assess the trends and impact among the significant and increasing number of American Jews who identify as Jewish and claim to have no religion.

In their paper, Sasson, Kadushin and Saxe recognize this issue when they write:

Were we to employ a more expansive definition of 'Jewish' to include anyone of Jewish ancestry who does not identify with another religion, then the overall level of Israel attachment would be somewhat lower. Moreover, if the population of 'Jews by ancestry' is increasing over time, as some analysts suggest, then including the group would put downward pressure on overall Israel attachment.

We (Cohen and Kelman) could not have put our core observation much better ourselves, albeit with the exception of the inaccurate nomenclature of "Jews by ancestry," to which we turn presently.

The above passage refers to "some analysts" who argue on behalf of the growth in Jews who do not identify Judaism as their religion. Who are these unnamed analysts? Anyone following the discourse of social scientists in our field would credit (and laud) Kadushin and Saxe (along with Barry Kosmin and Ariella Keysar as well as Jack Ukeles and Ron Miller) as among the leading proponents of this view (with which we heartily agree). As Jewish identity has become more fluid, as multiple identities have become more acceptable, and as what Charles Liebman once called the "package" of coherent Jewish identity dimensions unravels, the number of Jews who identify as Jewish but not with the Jewish religion grows apace. In fact, the Kadushin-Saxe (and others') analysis of the 2001 National Jewish Population Study argued for an undercount of the most marginally engaged Jews, of whom Jews with no religious preference (often intermarried, and often the children of intermarried parents) are a substantial population segment. Their argument has as much merit now as it did then. Jews-not-by-religion may be undercounted or overlooked, but they cannot be ignored in assessing the recent Jewish past and the prospective Jewish future.

The significance of excluding Jews-not-by-religion ("I'm Jewish but I have no religion") can be seen in the extent to which they trail Jews-by-religion ("I'm Jewish and my religion is Judaism") in bellwether measures of Jewish engagement. Even within the somewhat truncated NJPS (a sample nowhere near as truncated as the AJC sample), we find huge differences between Jews-by-religion and Jews-notby-religion. Two gaps between the two segments are particularly striking in synagogue membership (49 vs. 10\%), and in feeling very attached to Israel (33 vs. 
$10 \%$ ). Our colleagues were RIGHT to infer that "including the group [Jews-notby-religion] would put downward pressure on overall Israel attachment." They were WRONG to exclude this consideration in rejecting the idea that non-Orthodox Jews are growing more distant from Israel, or more broadly, in moving from the "consistent evidence" they could analyze to the complex inferences we are compelled to draw.

With respect to Jews-not-by-religion, we take issue with their paper on another plane: we utterly reject the term "Jews by ancestry," as an inadequate and misleading characterization of people who say they are Jews but also answer "none" when asked for their religion. To us, "Jews by ancestry" connotes Jews who recognize that one or more of their forebears were Jewish, but who do not necessarily identify as Jewish. Certainly, almost all "Jews-not-by-religion" are "Jews by ancestry;" but, not all "Jews by ancestry" are Jews (and they say so). Classifying or re-titling Jews-not-byreligion as Jews-by-ancestry significantly diminishes their standing within the Jewish population. In point of fact, the misnomer runs contrary to the major classificatory schema employed by social scientists in our field.

Surveys that manage to include Jews-not-by-religion (like the NJPS and local Jewish population studies such as those conducted by Ukeles Associates) find that they are highly linked to the intermarriage phenomenon. They are disproportionately the spouses of non-Jews or the Jewishly identifying children of Jewish and non-Jewish parents. Hence, any data set that fails to include Jews-not-byreligion dramatically under-estimates the impact of intermarriage on attachment to Israel. Data sets (such as the AJC series and the similarly conducted survey that we fielded in 2007) can be very valuable; but, in echoing words we have heard from Kadushin and Saxe with respect to the NJPS and other data sets: these data should be used with caution and proper consideration for theory, method, and context.

\section{It's Not Just About the (Available) Data}

As noted, Sasson et al. are entirely aware of these issues in sampling and classification. But, in their caution to draw inferences from the available data covering a part of the Jewish population, they refrain from speculating on the likely impact of the growing number of Jews-not-by-religion. They write, "No data exists to estimate whether and to what extent this population is increasing." No available data means, for them, no willingness to venture too far afield.

We understand our colleagues' caution, even if we do not share, their "strictconstructionist" approach to the data. We (Cohen and Kelman) see our professional roles differently. For us, the available "hard" evidence contributes to and shapes our interpretation of the world around us; but available hard data is not all we have. They stand alongside "soft" evidence, as well as side-knowledge, theory, and, ultimately what the great sociologist C. Wright Mills called, "The Sociological Imagination." While our work is data-informed, we hope it is theoretically rich, contextually situated, and sociologically imaginative. For Jewish social thinkers and public intellectuals, the roles that both we and our colleagues occupy in Jewish life, 
ultimately, it's not about the data. It's about the ideas and the people whose lives are impacted by them.

Approaching the question of Israel attachment only at the level of data neglects the broad terrain on which American Jewry is experiencing significant cultural, social and institutional change. Intermarriage, the waning influence and power of institutions, the decline in denomination affiliation among younger people, the dramatic growth of Jewish organizations outside of the federation-family system, the growth of the independent mega-donors and other individual philanthropists, and an increasing emphasis on meaning-seeking and purposefulness rather than ethnic bonds and loyalty point to significant changes in American Jewish life. Surely the relationship between American Jews and Israel is neither insulated nor isolated from these other trends, and only in that context can we truly understand what the data mean.

And, in this particular discourse (let's not call it a debate), our central idea is that Israel attachment among non-Orthodox American Jews is in decline, and ought not be a taken-for-granted tenet of American Jewish identities. The growth of intermarriage means that more such Jews and their children will adopt lifestyles that seem to militate against Israel attachment as a taken-for-granted pillar of their Jewish identities. The growth in intermarriage will produce more children with weak attachments to Israel, as well as more children who will identify as Jewsnot-by-religion. As a result, fewer non-Orthodox Jews will feel attached to Israel, even as those Jews who see their religion as Judaism (and not "none") will maintain stable ties to Israel in the years ahead. The available data, such as over-time series based upon interviews with the shrinking number of Jews-by-religion, that include the Orthodox, are valuable and useful. But they cannot and will not show declining trends in Israel attachment; in fact, Israel engagement levels in this population may well trend upward, even as the levels trend downward among all non-Orthodox Jews!

We think that given all we know, all we can discern, and all we can imagine, that the foregoing represents the best characterization of the matter at hand. All things considered, we think that non-Orthodox Jews in America, as a group, are growing more distant from Israel and will continue to do so.

When confronted with a vexing question with a troubling answer in plain sight, one of us recalls asking our grandmother, "What do you think?" And, turning the question back to us she'd ask, "Now, what do YOU think?"

So ... Do you (reader) think that with all the intermarriage, all the changes in Jewish identity, and all the growth in Jews-not-by-religion, that non-Orthodox Jews in the United States are just as attached to Israel as ever before? Really now, what do YOU think?

Open Access This article is distributed under the terms of the Creative Commons Attribution Noncommercial License which permits any noncommercial use, distribution, and reproduction in any medium, provided the original author(s) and source are credited. 


\section{Author Biographies}

Steven M. Cohen is Research Professor of Jewish Social Policy, Hebrew Union College-Jewish Institute of Religion, and Director of the Berman Jewish Policy Archive at NYU Wagner. He made aliyah in 1992 and lives both in Jerusalem and New York.

Ari Y. Kelman is an Associate Professor of American Studies at the University of California, Davis. He is the author of Station Identification: A Cultural History of Yiddish Radio (UC Press, 2009) and the editor of Is Diss a System: A Milt Gross Comic Reader (NYU Press, 2009) 